\title{
AKTIVITAS EKSTRAK ETANOL KULIT BUAH NANGKA (Artocapus heterophyllus) MENGHAMBAT PERTUMBUHAN BAKTERI Escherichia coli dan Staphylococcus aureus
}

\author{
Siti Mariam ${ }^{1 *}$, Lia Rahmania ${ }^{1}$, Lilik Sulastri $^{1}$ \\ Prodi S1 Farmasi Sekolah Tinggi Teknologi Industri dan Farmasi Bogor Indonesia \\ Korespondensi: sitimariam210467@gmail.com
}

\begin{abstract}
ABSTRAK
Senyawa aktif yang terkadung dalam buah nangka (Artocapus heterophyllus Lamk.) diantaranya tannin dan polifenol yang diketahui memiliki efek antibakteri. Perlu dilakukan penelitian untuk mengetahui komposisi senyawa kimia dan aktifitas antibakteri pada bakteri Staphylococcus aureus (gram positif) dan bakteri Escherichia coli (gram negative) dari limbah kulit buah nangka Ekstraksi kulit buah dengan metode maserasi menggunakan pelarut etanol 96\%. Metode difusi cakram digunakan untuk menguji aktivitas antibakteri dengan 3 kelompok perlakuan (terdiri dari kelompok konsentrasi $10 \%, 20 \%$, dan 30\%) serta 2 kelompok kontrol (chloramphenicol base sebagai control positif dan DMSO sebagai kontrol negative). Hasil penelitian menunjukkan bahwa 3 kelompok ekstrak kulit buah nangka mempunyai aktivitas antibakteri terhadap bakteri Staphylococcus aureus dan Escherichia coli. Aktivitas tertinggi terhadap bakteri Staphylococcus aureus pada konsentrasi $30 \%$ menghasilkan nilai diameter zona hambat rata-rata sebesar $10,76 \mathrm{~mm}$ termasuk kategori kuat dan pada bakteri Escherichia coli menghasilkan diameter zona hambat rata-rata sebesar 7,13 mm termasuk kategori sedang. Hasil Analisis data menggunakan ANOVA menunjukkan bahwa aktivitas antibakteri ekstrak kulit buah nangka berbeda nyata pada bakteri Staphylococcus aureus dan Escherichia coli. Hasil uji lanjut dengan Uji Duncan menunjukkan ekstrak kulit buah nangka mempunyai aktivitas antibakteri lebih tinggi pada bakteri Staphylococcus aureus dibanding bakteri Escherichia coli.
\end{abstract}

Kata Kunci : Antibakteri, Escherichia coli, kulit buah nangka, Staphylococcus aureus

\begin{abstract}
Jackfruit (Artocapus heterophyllus Lamk.) has several active substances such as tannin and polifenol which known to have antibacterial effect. The necessary of research to determine active substances of jackfruit peel and its antibacterial activity to Gram-positive bacteria Staphylococcus aureus (Gram-positive) and bacteria Escherichia coli (Gram-negative). Jackfruit peel was extracted using $96 \%$ ethanol solvent by maceration method. disc-The diffusion agar method was done using to antibacterial activity assay with 3 treatment groups (each group using 10\%, 20\% and 30\% concentration of jackfruit peel) and 2 control groups (chloramphenicol base as positive control and DMSO as negative control). The result of this study shows that jackfruit peel extract has antibacterial activity to Staphylococcus aureus and Escherichia coli. The highest antibacterial activity to Staphylococcus aureus was observed in $30 \%$ concentration with $10.76 \mathrm{~mm}$ average value of inhibition zone diameter and categorized as strong. For Escherichia coli bacteria, the average value of inhibition zone diameter was $7.13 \mathrm{~mm}$ and categorized as medium. Statistical analysis was done using ANOVA shows that antibacterial activity of jackpeel fruit was statistically significant for both Staphylococcus aureus and Escherichia coli bacteria. Statistical analysis was done using followed by Duncan test shows that antibacterial activity of jackfruit peel extract was higher on Staphylococcus aureus compared to Escherichia coli.
\end{abstract}

Keywords : Antibacterial, Escherichia coli, Jackfruit peel, Staphylococcus aureus 


\section{PENDAHULUAN}

Buah nangka (Artocarpus heterophyllus) tumbuh di daerah tropis, yang berbuah tanpa mengenal musim. Pohon nangka tumbuh di berbagai daerah di Indonesia. Menurut Kementerian Pertanian (2015), produksi buah nangka di Indonesia pada tahun 2014 mencapai 644.291 ton.

Buah nangka umumnya dikonsumsi sebagai bahan pangan, buah nangka juga dapat digunakan untuk pengobatan tuberculosis, gangguan limpa, malaria, demam, sakit gigi, disentri, diare, bisul, dan penyakit kulit, (Syamsul, 2008). Berbagai bagian dari pohon nangka juga digunakan untuk obat tradisional. Berdasarkan hasil penelitian buah nangka mengandung senyawa kimia polifenol dan tanin, umumnya polifenol dan tanin memiliki aktifitas antibakteri (Yuniarni et al., 2017).

Penelitian Swantara et al

(2011), menyatakan bahwa ekstrak metanol kulit batang nangka mempunyai aktivitas antibakteri terhadap Eschericia coli dan Staphylococcus aureus dengan zona hambat rata-rata masingmasing sebesar 7,0 $\mathrm{mm}$ dan 8,0 $\mathrm{mm}$. Hasil penelitian M.R Khan et al (2003) menyatakan bahwa ekstrak metanol buah nangka mempunyai aktivitas sebagai antibakteri terhadap bakteri Eschericia coli dan Staphylococcus aureus, menghasilkan diameter zona hambat rata-rata masing-masing sebesar $8,0 \mathrm{~mm}$.

Selama ini telah banyak pengolahan buah nangka menjadi produk konsumtif di masyarakat seperti dodol, keripik buah, manisan, sari buah, sirup, selai, dan pasta, tetapi pengolahan tersebut menghasilkan limbah kulit buah dan jerami nangka yang mencapai $65-80 \%$ berat keseluruhannya. (Sugiarti, 2003). Semakin banyak produk olahan yang berbahan dasar biji dan buah nangka, menyebabkan peningkatan jumlah limbah kulit buah nangka yang dihasilkan.

Pemanfaatan dari limbah nangka belum banyak dilakukan, saat ini limbah buah nangka hanya dibuang, sehingga perlu dicari cara memanfaatkan limbah kulit buah nangka sebagai solusi untuk mengatasi masalah tersebut. Penelitian dilakukan untuk meningkatkan pemanfaatan limbah kulit nangka diantaranya sebagai bahan alam sumber bahan baku antibakteri.

\section{METODE PENELITIAN}

Kulit buah nangka matang sebanyak 4 buah dipisahkan dari daging dan buah nangka, dicuci dengan air mengalir dan dipotong potong kecil.
Ditimbang $5 \mathrm{~kg}$ kulit buah nangka basah, dikeringkan menggunakan oven dengan suhu $40^{\circ} \mathrm{C}$ selama lebih kurang 4 hari sampai diperoleh simplisia kering. Simplisia kering diperkecil ukurannya menggunakan blender dan diayak dengan ukuran 40 mesh.

Sebanyak 600 g serbuk simplisia kulit buah nangka kering dimaserasi menggunakan etanol 96\% dengan cara merendam satu bagian serbuk dengan 10 bagian pelarut selama 24 jam sambil sesekali dilakukan pengadukan. Dilakukan remaserasi selama 2 x 24 jam menggunakan pelarut yang sama. Kemudian, filtrat yang diperoleh dipekatkan dengan cara menguapkan pelarutnya pada rotary vacuum evaporator sampai pelarut habis menguap. pada suhu $60^{\circ} \mathrm{C}$

Aktivitas antibakteri dilakukan secara in vitro menggunakan metode difusi agar dengan menggunakan kertas cakram pada media agar yang telah diinokulasi bakteri Staphylococcus aureus dan Escherichia coli. Larutan uji ekstrak etanol kulit buah nangka menggunakan konsentrasi $10 \%, \quad 20 \%$, dan $30 \%$. Chloramphenicol base (kontrol positif) dan DMSO (kontrol negative). Diambil sebanyak 1 ose kultur bakteri dari Nutrient Agar, diinokulasikan kembali ke dalam media Nurient Broth dengan volume $1 \mathrm{ml}$, selama 24 jam diinkubasi pada suhu $37^{\circ} \mathrm{C}$. Kultur bakteri dari media Nutrient Broth dituang pada cawan petri steril dan ditambahkan media Nutrient Agar cair, kemudian dihomogenkan dan tunggu hingga padat. Kertas cakram steril, direndam dalam ekstrak kulit buah nangka konsentrasi 10\%, 20\% dan 30\%, larutan Chloramphenicol base dan larutan DMSO Kertas caktram selanjutnya ditempelkan pada permukaan media NA yang sudah ditanambiakan bakteri Staphylococcus aureus dan Escherichia coli. Biakan dimasukkan dalam incubator untuk diinkubasi selama 24 jam pada suhu $37^{\circ} \mathrm{C}$.

Diameter zona hambat dari masingmasing perlakuan diukur diameternya dalam mili meter $(\mathrm{mm})$ setelah masa inkubasi 24 jam, yang ditunjukkan dengan terbentuknya zona bening di sekeliling kertas cakram sebagai penghambatan terhadap pertumbuhan bakteri dalam satuan milimeter. Diameter zona hambat rata rata dapat dikategorikan kekuatan daya antibakterinya berdasarkan penggolongannya (Jannata et al., 2014). Diameter zona hambat rata-rata menujukkan aktivitas ekstrak kulit buah nangka menghambat pertumbuhan bakteri. Diameter zona hambat rata-rata hasil pengukuran sebagai gambaran aktivitas. 
antibakteri ekstrak etanol kulit buah nangka terhadap bakteri Staphylococcus aureus dan Escherichia coli dianalisa secara statistik menggunakan metode One way Anova (analisa varian satu arah) dengan taraf kepercayaan $95 \%$ atau $\alpha=0,05$. Bila hasil analisis menunjukkan perbedaan yang nyata, maka analisis statistic dilanjutkan dengan menggunakan uji Duncan.

\section{HASIL DAN PEMBAHASAN}

Simplisia kulit buah nangka dibuat menjadi Serbuk simplisia yang dihasilkan dari $\pm 5 \mathrm{~kg}$ kulit buah nangka yaitu sebanyak $890 \mathrm{~g}$. Simplisia serbuk dibuat dengan tujuan untuk meningkatkan luas permukaan bidang sentuh antara serbuk simplisia dengan pelarut yang digunakan.

Hasil ekstraksi serbuk kulit buah nangka sebanyak $600 \mathrm{~g}$ diperoleh ekstrak kental 49,51 g sehingga diperoleh rendemen sebesar 8,25\% berupa ekstrak kental berwarna coklat tua.

Hasil uji penapisan fitokimia ekstrak kulit buah nangka dapat dilihat pada tabel di bawah :

\begin{tabular}{|l|l|c|}
\hline Uji & Reagent & Hasil \\
\hline Alkaloid & Bouchardat & - \\
& Mayer & - \\
& Dragendorf & - \\
\hline Saponin & & + \\
\hline Tannin & & + \\
\hline Flavonoid & & + \\
\hline Triterpenoid & & - \\
\hline Steroid & & - \\
\hline
\end{tabular}

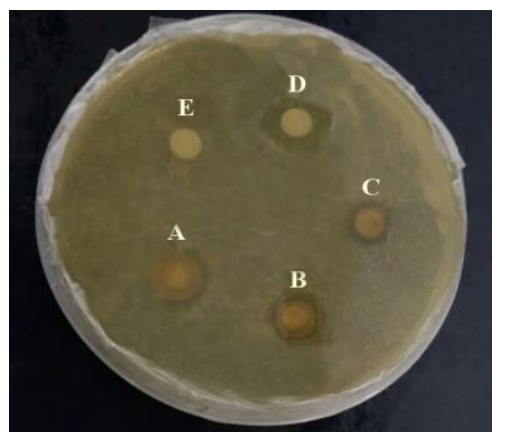

(a) Staphylococcus aureus
Hasil uji aktivitas ekstrak kulit buah nangka sebagai antibakteri menggunakan dengan difusi cakram, terbentuk zona bening di sekeliling kertas cakram yang menunjukkan terjadinya penghambatan terhadap pertumbuhan bakteri pada masing masing perlakuan. Zona bening yang terbentuk diukur menggunakan jangka sorong (caliper) dalam satuan milimeter ( $\mathrm{mm}$ ). Chloramphenicol base sebagai kontrol positif berfungsi sebagai pembanding terhadap ekstrak kulit buah nangka. Pilihan antibiotik Chloramphenicol base sebagai control positif sebagai broad spectrum (spektru luas). Kontrol negative menggunakan DMSO digunakan sebagai kontrol negatif karena digunakan untuk mengekstrak kulit buah nangka. DMSO merupakan suatu pelarut yang mudah diserap ke dalam epitel simplisia tetapi tidak merusak sel, dan efektif melarutkan hampir semua senyawa baik senyawa non polar maupun senyawa polar (Merck Millipore, 2016).

Zona bening hasil uji ekstrak etanol kulit buah nangka terhadap pertumbuhan bakteri Staphylococcus aureus dan Escherichia coli setelah masa inkubasi 24 jam pada Gambar 1 di bawah.

Gambar 1. Zona Hampat Pertumbuhan Bakteri dari Ekstrak Kulit Buah Nangka

Keterangan: A= Ekstrak 10\%, B=Ekstrak 20\%, C=Ekstrak30\%, D=Kontrol positif, dan E=Kontrol negatif

Pada Gambar 1 terlihat adanya hambatan pertumbuhan bakteri berupa zona bening sekitar cakram pada media Nutrient Agar (NA). Hal ini membuktikan bahwa ekstrak kulit buah nangka mempunyai aktivitas antibakteri terhadap

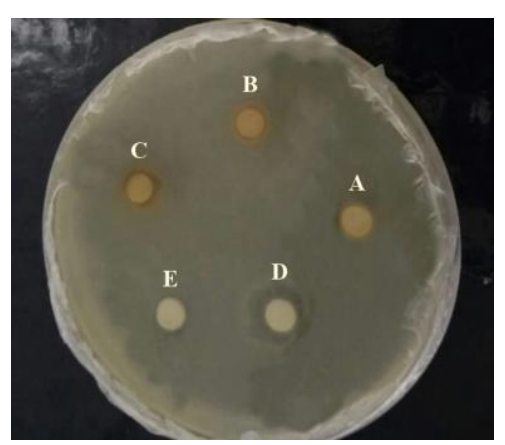

(b) Escherichia coli pertumbuhan bakteri Staphylococcus aureus dan Escherichia coli. Rata-rata diameter zona hambat dari berbagai konsentrasi ditampilkan pada gambar 2 di bawah 


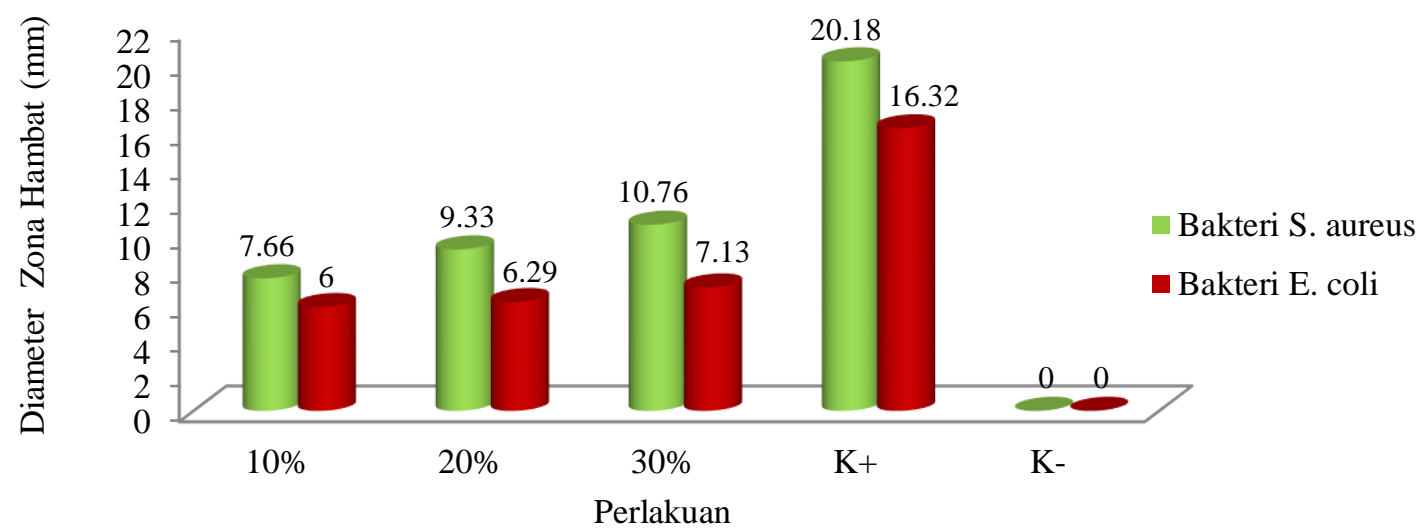

Gambar 2. Diameter Zona Hambat Rata-rata Ekstrak Kulit Buah Nangka Terhadap Pertumbuhan Bakteri Staphylococcus aureus dan Escherichia coli

Menurut Jannata et al. (2014), klasifikasi respon penghambatan terhadap bakteri berdasarkan diameter zona bening yang terbentuk terdiri atas 4 kelompok yaitu:

1. diameter $\leq 5 \mathrm{~mm} \rightarrow$ lemah

2. diameter $5-10 \mathrm{~mm} \rightarrow$ sedang

3. diameter $10-20 \mathrm{~mm} \rightarrow$ kuat

4. diameter $\geq 20 \mathrm{~mm} \rightarrow$ sangat kuat

Berdasarkan grafik di atas diperoleh hasil bahwa semua konsentrasi ekstrak kulit buah nangka mempunyai aktivitas antibakteri terhadap pertumbuhan bakteri Staphylococcus aureus dengan kategori sedang pada konsentrasi $10 \%$ dan $20 \%$, serta kategori kuat pada konsentrasi $30 \%$. Sedangkan pada bakteri Escherichia coli didapatkan hasil dengan kategori sedang pada semua konsentrasi yaitu konsentrasi 10\%, 20\%, dan 30\%. Pada kontrol negatif (DMSO) tidak terlihat adanya zona bening yang terbentuk di sekitar kertas cakram, hal tersebut membuktikan bahwa pelarut tidak mempunyai aktivitas antibakteri

Dengan membandingkan luas zona bening yang dihasilkan pada masing-masing perlakuan, dapat diketahui bahwa zona bening yang dihasilkan akan semakin lebar seiring dengan peningkatan konsentrasi dan semakin kecil seiring menurunnya konsentrasi sampel yang diuji. Hal tersebut berarti bahwa peningkatan konsentrasi ekstrak menunjukkan peningkatan kadar senyawa aktif yang berfungsi sebagai antibakteri, sehingga dapat menghambat pertumbuhan bakteri semakin kuat. Menurut Pelczar dan Chan (2005), semakin tinggi konsentrasi suatu bahan antibakteri maka aktivitas antibakterinya semakin kuat.
Aktivitas ekstrak kulit buah nangka menghambat pertumbuhan bakteri Staphylococcus aureus maupun bakteri Escherichia coli karena senyawa kimia yang terkandung di dalamnya.

Berdasarkan hasil penapisan fitokimia, kulit buah nangka mengandung senyawa tanin, flavonoid, dan saponin. Mekanisme kerja tanin dalam membunuh bakteri adalah dengan cara menghambat sintesa dinding sel. Dinding sel bakteri tersusun atas senyawa peptidoglikan yang tersusun dari polisakarida dan campuran rantai polipeptida yang tinggi. Sifat keras pada dinding sel disebabkan oleh ikatan saling silang (cross linking) rantai peptida yang merupakan hasil reaksi transpeptidasi yang oleh beberapa enzim. Target kerja tanin pada dinding sel bakteri dengan cara mempengaruhi ikatan polipeptida, sehingga pembentukan dinding sel kurang sempurna, sehingga sel bakteri mudah lisis dan bakteri kemudian mati (Sari, 2011).

Flavonoid bekerja sebagai bakterisida, dengan cara membentuk kompleks dengan protein ekstraseluler sehingga terjadi kerusakan membtran sel bakteri. Hal tersebut menyebabkan sel bakteri mudah dimasuki air secara tidak terkontrol, terjadi pembengkakan dan pecahnya sel bakteri (Pelczar et al., 2005). Flavonoid juga bekerja dengan cara denaturasi protein sel bakteri, terbentuk ikatan hydrogen komplek antara flavonoid dengan protein sel bakteri yang menyebabkan struktur dinding sel dan membran sitoplasma bakteri tidak stabil dan kehilangan aktivitas biologinya. Permeabilitas sel bakteri terganggu dan tidak berfungsi yang 
menyebabkan bakteri lisis yang mengakibatkan kematian sel bakteri (Harborne, 1987).

Mekanisme kerja saponin dengan cara merusak berikatan dengan lipopolisakarida pada membran sel, ikatan tersebut menyebabkan peningkatan permeabilitas dinding sel. Terjadi penurunan tegangan permukaan dinding sel yang disebabkan oleh saponin yang terkandung dalam ekstrak kulit buah nangka, dan senyawa antibakteri lain akan mudah memasuki sel bakteri dan mengganggu metabolisme sehingga bakteri menjadi mati (Karlina et al., 2013).

Berdasarkan pada analisis data yang dilakukan semua data yang diuji terdistribusi

\section{KESIMPULAN}

1. Ekstrak kulit buah nangka mengandung senyawa aktif flavonoid, tanin dan saponin yang berkhasiat sebagai antibakteri.

2. Ekstrak kulit buah nangka mampu menghambat pertumbuhan bakteri Staphylococcus aureus dengan kategori sedang pada konsentrasi $10 \%$ dan $20 \%$, serta kategori kuat pada konsentrasi 30\%, sedangkan pada bakteri Escherichia coli memiliki kategori sedang pada semua konsentrasi.

3. Aktivitas antibakteri tertinggi terhadap bakteri Staphylococcus aureus pada konsentrasi 30\% dengan rata-rata diameter zona hambat sebesar 10,76 mm, sedangkan. bakteri Escherichia coli sebesar 7,13 mm. Kontrol positif chloramphenicol base mampu menghambat pertumbuhan bakteri Staphylococcus aureus dengan daya hambat sebesar 20,18 $\mathrm{mm}$ dan pada bakteri

\section{DAFTAR PUSTAKA}

1. Guilherme S, Jose et all. 2004. Aroms Volatiles From Two Fruit Varietas of Jack Fruit (Artocarpus heterophyllus Lam). Food Chemistry 1 195-197.

2. Harborne, J.B. 1987. Metode Fitokimia. Edisi 2. Padmawinata., penerjemah. Bandung: ITB.

3. Jannata, R.H., Gunadi, A., Ermawati, T. 2014. Daya Antibakteri Ekstrak Kulit Apel Manalagi (Malus sylvestris Mill.) Terhadap Pertumbuhan Streptococcus mutans. $e$ Jurnal Pustaka Kesehatan 2(1): 23-28. normal $(\mathrm{p}>0,05)$ kemudian, dilakukan uji satu arah Anova dengan taraf kepercayaan 95\%. Berdasarkan pada uji tersebut terdapat pengaruh yang signifikan antara setiap konsentrasi ekstrak kulit buah nangka terhadap daya hambat yang dihasilkan ( $p<0,05)$. Selanjutnya dilakukan uji lanjutan Duncan, berdasarkan pada uji tersebut dapat ditarik kesimpulan bahwa terdapat perbedaan yang nyata daya hambat bakteri pada setiap konsentrasi ekstrak kulit buah nangka ( $p$ > $0,05)$. Terdapat perbedaan yang nyata antara aktivitas ekstrak kulit buah nangka dengan control positif .

Escherichia coli sebesar $16,32 \mathrm{~mm}$. Sedangkan pada kontrol negatif (DMSO) tidak memiliki daya hambat.

4. Berdasarkan uji statistik Anova dan uji lanjutan Duncan dapat disimpulkan bahwa terdapat perbedaan yang signifikan dalam menghambat pertumbuhan bakteri Staphylococcus aureus dan bakteri Escherichia coli pada subset yang berbeda.

\section{SARAN}

. Perlu dilakukan isolasi lebih lanjut terhadap ekstrak kulit buah nangka untuk menghasilkan senyawa murni aktif yang terkandung sehingga meningkatkan aktivitasnya sebagai antibakteri.

Perlu dilakukan uji antibakteri dengan metode lain sehingga bisa dihitung nilai Konsentrasi Hambat Minimum (KHM) dan menggunakan metode ekstraksi lainnya terhadap bakteri gram positif dan gram negatif lainnya.

4. Karlina, C.Y, M. Ibrahim dan G. Trimulyono. 2013. Aktivitas Antibakteri Ekstrak Herbal Krokot (Portulaca oleraceae L.) Terhadap Staphylococcus aureus dan Escherichia coli. Journal UNESA LenteraBio. 2(1) : 87-93.

5. M.R. Khan et al. 2003. Fitoterapia 74 . Hlm. 501-505.

6. Merck,Millipore. 2016. Dimetil Sulfoksida [terhubungberkala]. http://www.merckmillip ore.com/ID/id/product/Dimetilsulfoksida,M DA_CHEM-102952.html $[16$ November 2016]. 
75| Siti Mariam et, al.,( Aktivitas Ekstrak Etanol Kulit Buah Nangka ...)

7. Pelczar, M.J., Chan, E.C.S. 2005. Dasardasar Mikrobiologi 2. Hadioetomo R.S., Imas T., Tjitrosomo S.S., Angka S.L., penerjemah. Jakarta: Universitas Indonesia Press. Hlm: 450, 512.

8. Sari, F.P. 2011. Ekstraksi Zat Aktif Antimikroba dari Tanaman Yodium (Jatropha multifida Linn) sebagai Bahan Baku Alternatif Antibakteri Alami. Semarang: Fakultas Teknik Universitas Diponegoro.

9. Sugiarti. 2003. Pengaruh Asam Sitrat dan Gula terhadap Mutu Selai dari Dami Nangka Varietas Nangka Kunir (Artocarpus heterophyllus). ITB, Jawa Barat.

10.Swantara, D.M. et al. 2011. Uji Aktivitas Antibakteri Fraksi Kulit Batang Nangka. Jurnal Kimia 5 (1), Januari 2011 : 1-8 2 : Jurusan Kimia FMIPA Universitas Udayana, Bukit Jimbaran.

11.Syamsul, A. 2008. Ilmu Kimia dan Kegunaan Tumbuh-Tumbuhan Obat Indonesia, Jilid 1, Bandung, Penerbit ITB, 69.

12.Yuniarni, U., Wiyanti, E., Sunardi, C. 2017. Skrining Potensi Antibakteri Ekstrak Etanol Buah Nangka Muda (Artocarpus heterophyllus Lamk.) Terhadap Bakteri Penyebab Diare. Jurnal Farmasi Galenika Volume 01 No. 02 ISSN: 2406-9299. 